Chemical Technology

Division

Chemical Technology Division

Chemical Technology Division

Chemical Technology

\title{
Characterization and Recovery of Solvent Entrained During the Use of Centrifugal Contactors
}

Division

Chemical Technology

Division

Chemical Technology

Division

Chemical Technology

Division

Chemical Technology

Division

Chemical Technology

Division

Chemical Technology

Division

Chemical Technology

Division

Chemical Technology

Division

Chemical Technology

Division

Chemical Technology

Division

\author{
by H. A. Arafat, M. C. Hash,
A. S. Hebden, and R. A. Leonard \\ by H. A. Arafat, M. C. Hash,
A. S. Hebden, and R. A. Leonard
}

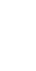


Argonne National Laboratory, with facilities in the states of Illinois and Idaho, is owned by the United States Government and operated by The University of Chicago under the provisions of a contract with the Department of Energy.

DISCLAIMER
This report was prepared as an account of work sponsored by an agency of
the United States Government. Neither the United States Government nor
any agency thereof, nor The University of Chicago, nor any of their
employees or officers, makes any warranty, express or implied, or assumes
any legal liability or responsibility for the accuracy, completeness, or
usefulness of any information, apparatus, product, or process disclosed, or
represents that its use would not infringe privately owned rights. Reference
herein to any specific commercial product, process, or service by trade name,
trademark, manufacturer, or otherwise, does not necessarily constitute or
imply its endorsement, recommendation, or favoring by the United States
Government or any agency thereof. The views and opinions of document
authors expressed herein do not necessarily state or reflect those of the
United States Government or any agency thereof, Argonne National
Laboratory, or The University of Chicago.

Available electronically at http://www.doe.gov/bridge

Available for a processing fee to U.S. Department of Energy and its contractors, in paper, from:

U.S. Department of Energy

Office of Scientific and Technical Information

P.O. Box 62

Oak Ridge, TN 37831-0062

phone: (865) 576-8401

fax: (865) 576-5728

email: reports@adonis.osti.gov 


\title{
ANL-02/08
}

\section{ARGONNE NATIONAL LABORATORY}

9700 South Cass Avenue

Argonne, IL 60439

\section{CHARACTERIZATION AND RECOVERY OF SOLVENT ENTRAINED DURING THE USE OF CENTRIFUGAL CONTACTORS}

\author{
by
}

H. A. Arafat, M. C. Hash, A. S. Hebden, and R. A. Leonard

October 2001 


\section{TABLE OF CONTENTS}

ABSTRACT.

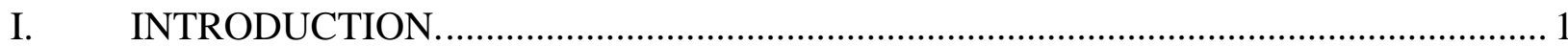

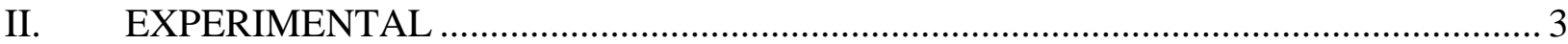

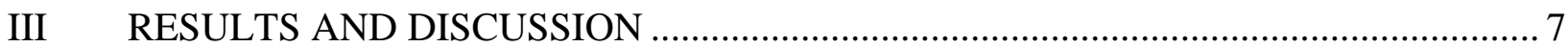

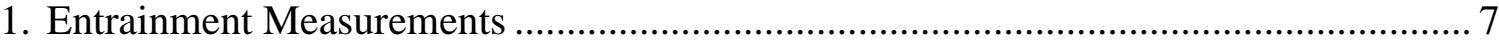

2. Droplet Size Distribution of Entrained Solvent ......................................................... 8

3. Decanter Tank Sizing …………………………………..................................... 10

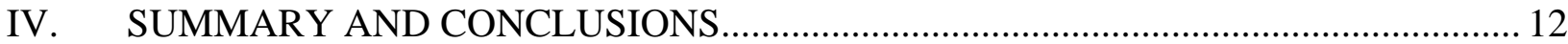

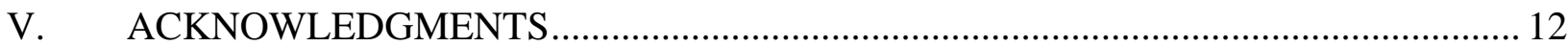

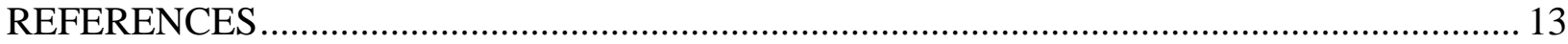

APPENDIX A. ENTRAINMENT CALCULATION DATA ……………………………....... 14

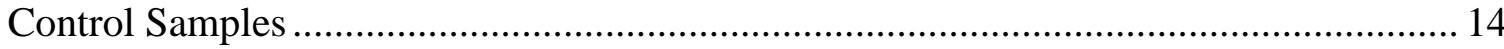

Entrainment Measurements...................................................................................... 16

APPENDIX B. C CUMULATIVE DROPLET SIZE DISTRIBUTION DATA ............................ 17

APPENDIX C. CALCULATIONS FOR SOLVENT RECOVERY IN A CSSX PILOT-PLANT DECANTER TANK 


\section{LIST OF FIGURES}

No.

$\underline{\text { Title }}$

$\underline{\text { Page }}$

1. Flowsheet for the Proposed CSSX Process Pilot Plant at SRS ...................................... 2

2. Experimental 4-cm Contactor Used for Decanter Tests................................................. 4

3. Schematic of the Experimental Setup for the Decanter Tests ..................................... 6

4. Size Distribution of Organic Droplets Entrained in Aqueous Effluents .......................... 9

\section{LIST OF TABLES}

$\underline{\text { No. }}$

$\underline{\text { Title }}$

1. Mixing Intensity for Different Rotor Sizes ........................................................... 5

2. Summary of Entrainment Measurement Tests ................................................... 7

3. Average Droplet Size in Raffinate and Strip Effluents ............................................ 10

A-1. Measurement of Control Samples by ORNL Using the Non-Modified Technique.......... 14

A-2. Measurements of Control Samples by ORNL Using the Modified Technique ............... 15

A-3. Entrainment Measurements by ORNL Using the Modified Technique.......................... 16

B-1. Cumulative Droplet Size Distribution for the Strip Effluent .................................... 17

B-2. Cumulative Droplet Size Distribution for the Aqueous Raffinate ............................... 18 


\title{
CHARACTERIZATION AND RECOVERY OF SOLVENT ENTRAINED DURING THE USE OF CENTRIFUGAL CONTACTORS
}

\author{
by \\ H. A. Arafat, M. C. Hash, A. S. Hebden, and R. A. Leonard
}

October 31, 2001

\begin{abstract}
In this work, we determined how a decanter for the aqueous effluents would work for solvent extraction operations using a centrifugal contactor. Solvent entrainment was measured in the raffinate and strip aqueous effluents in the caustic-side solvent extraction (CSSX) process. Values were obtained for both the solvent concentration and its droplet size distribution. The mixing intensity of the two phases in the mixing zone of the contactor was used to simulate the performance of lab-scale, pilot-plant, and plant-scale contactors. The droplet size distributions were used to estimate the amount of solvent that would be recovered using a decanter tank. It was concluded that the performance of decanter tanks will not be as effective in solvent recovery in the CSSX plan as that of other equipment, such as centrifuges and coalescers. Future testing is recommended to verify the performance of this alternative equipment.
\end{abstract}

\section{INTRODUCTION}

About 34 million gallons of high-level radioactive waste are currently stored in underground tanks at the Savannah River Site (SRS) in Aiken, South Carolina [LEVENSON2000]. Recently, a process developed at Oak Ridge National Laboratory (ORNL), in collaboration with Argonne National Laboratory (ANL) and SRS, was selected to remove cesium-137 $\left({ }^{137} \mathrm{Cs}\right)$ from the waste prior to immobilizing the waste in low-level grout. The treatment technology, which is a caustic-side solvent extraction (CSSX) process, will utilize a multistage centrifugal contactor to extract ${ }^{137} \mathrm{Cs}$ from the waste [LEONARD-2000]. The solvent used in this process consists of four components: (1) an extractant, calix[4]arene-bis(tertoctylbenzo-crown-6), designated $\mathrm{BoBCalixC6}$, which is a calixarene crown that is very specific for cesium extraction, (2) a modifier, 1-(2,2,3,3, -tetrafluoropropoxy)-3-(4-sec-butylphenoxy)-2propanol, also called Cs-7SB, which is an alkyl aryl polyether that keeps the extractant dissolved in the solvent and increases its ability to extract cesium in the extraction section, (3) a suppressant, trioctylamine (TOA), which suppresses effects from organic impurities to ensure that the cesium can be back-extracted from the solvent in the strip section, and (4) a diluent, Isopar ${ }^{\circledR} \mathrm{L}$, which is a mixture of branched hydrocarbons. The baseline solvent composition is $0.01 \underline{\mathrm{M}}$ BoBCalixC6, $0.5 \underline{\mathrm{M}} \mathrm{Cs}-7 \mathrm{SB}$, and $0.001 \underline{\mathrm{M}}$ TOA in Isopar ${ }^{\circledR} \mathrm{L}$ and is designated the "CSSX solvent." 
The process flowsheet for a proposed $1 / 100^{\text {th }}$ scale pilot plant at SRS is shown in Fig. 1 . In this flowsheet, cesium will be extracted from the SRS waste solution in the extraction section, leaving behind a decontaminated aqueous raffinate. The cesium will then be removed from the Cs-loaded solvent in the strip section. The aqueous strip solution containing the Cs will then be sent to the Defense Waste Processing Facility (DWPF) to undergo a vitrification process. The decontaminated waste raffinate is sent to the saltstone waste disposal facility. During proof-ofconcept tests performed at ANL in FY01, a setup similar to that shown in Fig. 1 was used. The difference between the two setups, besides the changes in flow rates, is that the ANL flowsheet had 15 extraction, 2 scrub, and 15 strip stages.

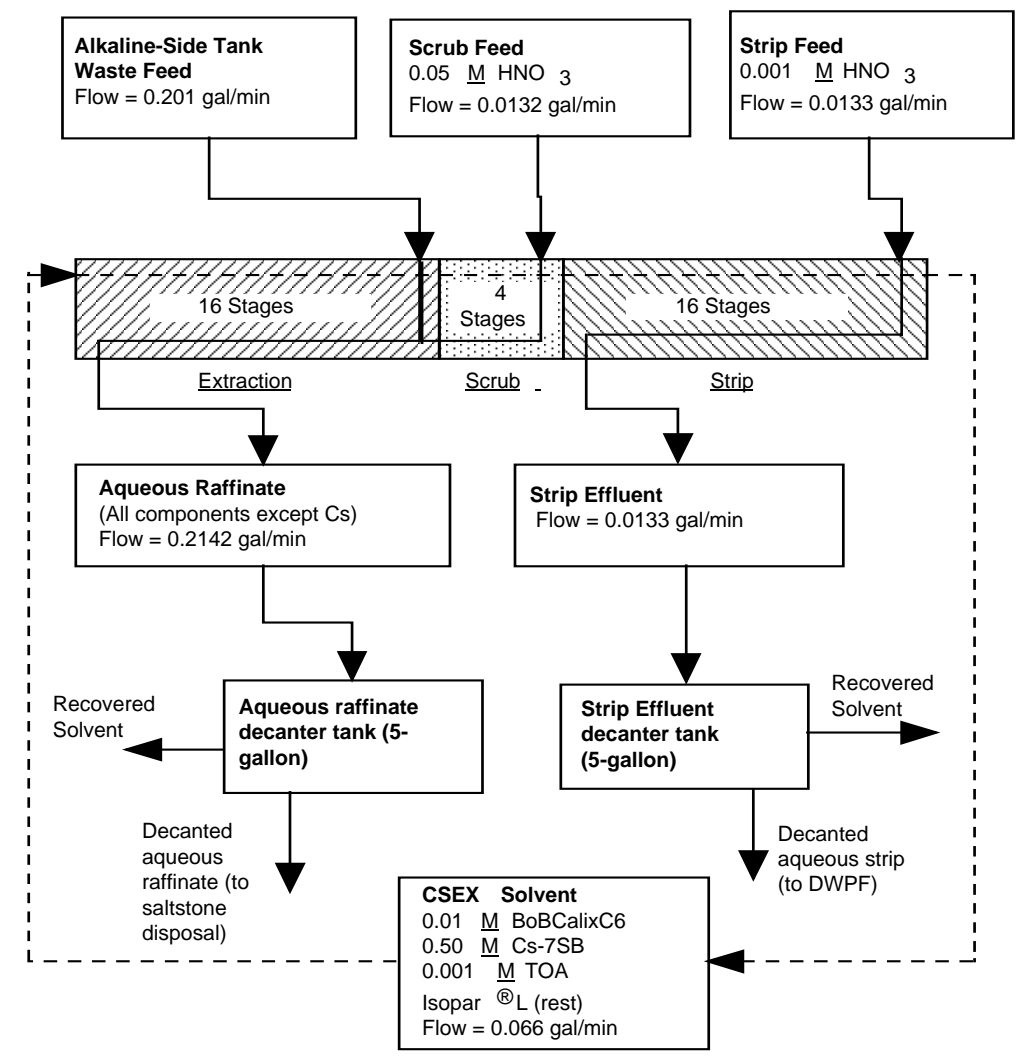

Fig. 1. Flowsheet for the Proposed CSSX Process Pilot Plant at SRS

When the CSSX process is carried out in a centrifugal contactor, losses of the organic solvent occur via two routes: (1) natural partitioning (via solubility) of the solvent components between the aqueous and organic phases, and (2) entrainment (or entrapment) as droplets dispersed within the aqueous phase. The partitioning limit of BoBCalixC6 is $3.3 \mathrm{E}-8 \underline{\mathrm{M}}$ in the caustic raffinate solution and 8.9E-7 $\underline{\mathrm{M}}$ in the strip solution [MASKARINEC-2001 (a)]. The partitioning limit of the modifier is less than $1 \mathrm{E}-5 \underline{\mathrm{M}}$ in the caustic raffinate solution and 7.41E-5 $\underline{\mathrm{M}}$ in the strip solution [MOYER-2001]. Based on a $20.1 \mathrm{gal} / \mathrm{min}$ plant-scale operation [HODGES-2000] for 240 day/yr, the total annual cost of BoBCalixC6 lost via partitioning alone is estimated to be $\$ 426,000 / \mathrm{yr}$, assuming the extractant cost at $\$ 150 / \mathrm{g}$. The total annual cost of 
modifier lost via partitioning is estimated to be $\$ 207,000 / y r$ for plant-scale operation. This cost is based on modifier cost of $\$ 1.5 / \mathrm{g}$, which is the projected commercial-production market value [BONNESEN-2001]. Thus, the total annual cost of BoBCalixC6 and modifier lost via partitioning is about $\$ 0.6 \mathrm{M} / \mathrm{yr}$. The amount of solvent lost as entrainment depends on the plant operation, including process upsets that could cause this loss to increase. Using a decanter tank, for example, will help recover part of the entrained solvent, although it cannot recover any dissolved solvent. It was expected that the amount of solvent lost via entrainment would be much larger than that lost via solubility. Therefore, solvent recovery efforts here are focused on minimizing entrainment as the primary route for reducing solvent loss.

Due to the vigorous mixing of the aqueous and organic phases within the contactor unit, droplets of the solvent become entrained in the aqueous phase exiting the contactors. Such entrainment has been observed during proof-of-concept tests at ANL. Similarly, SRS has observed some entrainment, ranging mainly from 0.01 to $0.4 \%$ and not exceeding $1 \%$, during the real-waste test performed there [CAMPBELL-2001]. Solvent entrainment occurs both in the strip effluent and the decontaminated raffinate. It is desirable to recover the entrained solvent from both aqueous flows for two reasons: (1) to maintain the organic contents of the aqueous effluents within the limits set for the DWPF and the saltstone disposal facilities, and (2) to reduce the cost of the CSSX process by recovering the solvent. The current estimate of solvent cost for the CSSX process is about $\$ 1900 / \mathrm{L} ; 87 \%$ of this cost is attributed to the extractant, BoBCalixC6, and $13 \%$ is attributed to the modifier, Cs-7SB. A number of options are being evaluated for the recovery of the entrained solvent. One of these options is to use settling (decanting) tanks. The pilot-plant flowsheet in Fig. 1 shows two 5-gallon decanter tanks, one for each aqueous effluent. The amount of the organic phase separated in a decanter tank depends on the size distribution of the dispersed (entrained) organic droplets, decanter size and geometry, and the total volume of entrained solvent. In the current work, we determined the droplet size distribution as well as the total volume of the entrained solvent.

\section{EXPERIMENTAL}

In order to design a decanter tank for a specific solvent recovery, it is necessary to obtain the size distribution of entrained solvent droplets. The experimental work described below was performed to obtain this size distribution by contacting the two phases under conditions simulating those of the actual contactor units. A single-stage, variable-speed, 4-cm centrifugal contactor was used in the decanter tests. As shown in Fig. 2, the contactor housing was a transparent acrylic block so that the operation and liquid height in the mixing zone could be observed. 


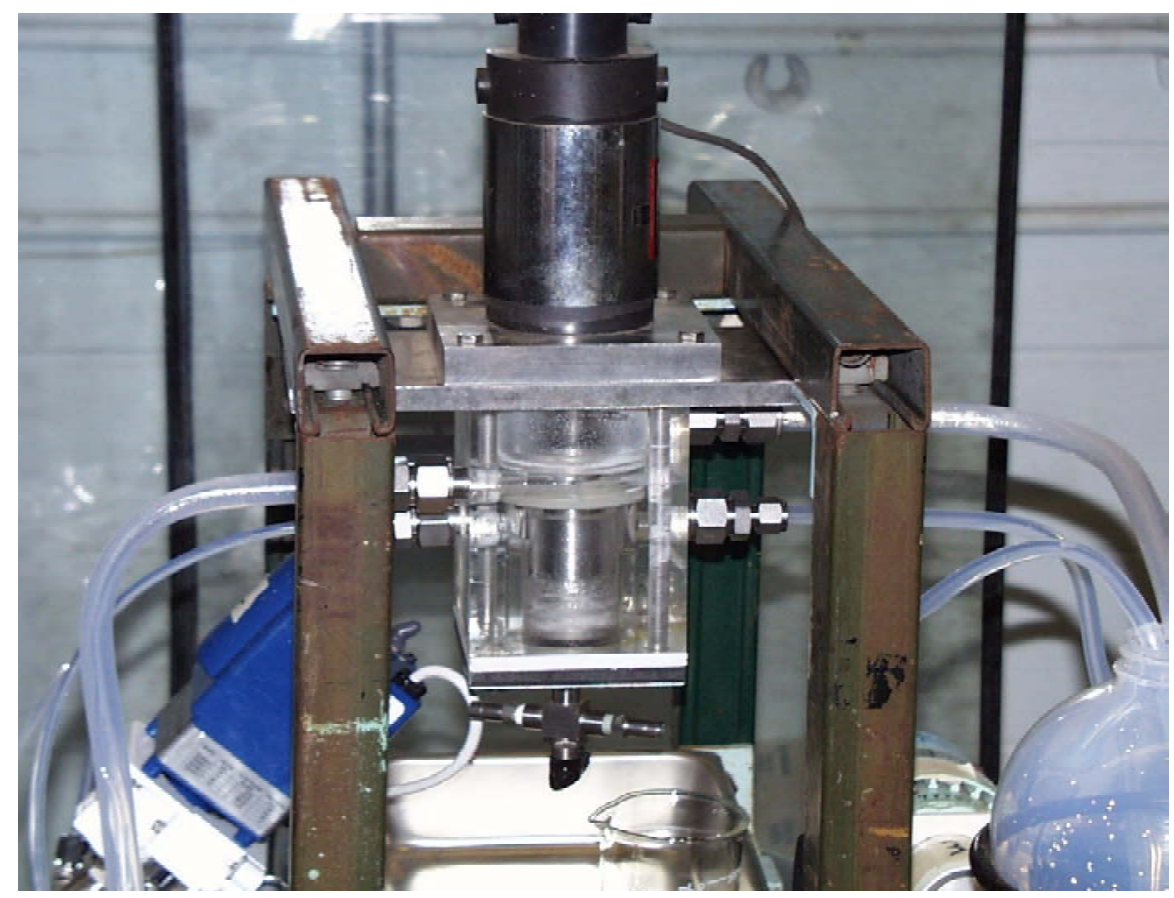

Fig. 2. Experimental 4-cm Contactor Used for Decanter Tests

The 4-cm acrylic-housing unit was used to simulate the performance of the 2-, 4-, and 25$\mathrm{cm}$ contactors by using the appropriate mixing intensity. We chose these three sizes because the 2-cm contactor was used in CSSX proof-of-concept tests, the 4-cm contactor is an approximation of a pilot-plant unit, and the $25-\mathrm{cm}$ contactor is an approximation of a plant-scale unit. The mixing intensity experienced by the liquid in the mixing zone $(\varepsilon)$ is defined as the mean rate of energy dissipation per unit mass in $\mathrm{W} / \mathrm{kg}$ :

$\varepsilon=\frac{P}{m}$

where

$P=$ mean rate of energy dissipation in fluid, $\mathrm{W}$, and

$m=$ mass of fluid, $\mathrm{kg}$

In order to calculate $\varepsilon$, the following correlations are used. They are derived from [KNUDSEN-1958]:

$P=0.0261 \mathrm{H}_{\mathrm{C}} \mathrm{r}_{\mathrm{R}, \mathrm{O}}^{3.75}(\mathrm{j} \omega)^{2.75} \rho^{0.75}\left(\mu / \Delta \mathrm{r}_{\mathrm{C}}\right)^{0.25}$

where

$\mathrm{H}_{\mathrm{C}}=$ liquid height in the annular mixing zone, $\mathrm{m}$

$\mathrm{r}_{\mathrm{R}, \mathrm{O}}=$ radius to the outside surface of the rotor, $\mathrm{m}$

$\Delta \mathrm{r}_{\mathrm{C}}=$ width of the gap in the annular mixing zone, $\mathrm{m}$ 
$\mu=$ viscosity of the bulk liquid or continuous phase of the dispersion, $\mathrm{Pa} \bullet \mathrm{s}$

$\rho=$ fluid or dispersion density, $\mathrm{kg} / \mathrm{m}^{3}$

$\omega=$ angular velocity of the rotor, $\mathrm{rad} / \mathrm{s}$, and

$\mathrm{j}=0.0554\left(\log \mathrm{N}_{\mathrm{Re}}\right)+1.368,3 \times 10^{3}<\mathrm{N}_{\mathrm{Re}}<1 \times 10^{6}$

where $\mathrm{N}_{\mathrm{Re}}$ is the Reynolds number, defined as

$\mathrm{N}_{\mathrm{Re}}=2 \mathrm{j} \rho \omega \mathrm{r}_{\mathrm{R}, \mathrm{O}} \Delta \mathrm{r}_{\mathrm{C}} / \mu$

for the annular mixing zone. A summary of mixing intensity calculations for the 2-, 4-, and 25cm contactors is shown in Table 1.

Table 1. Mixing Intensity for Different Rotor Sizes

\begin{tabular}{|c|c|c|c|}
\hline $\begin{array}{c}\text { Rotor Size, } \\
\mathrm{cm}\end{array}$ & $\begin{array}{c}\text { Speed, } \\
\mathrm{rpm}\end{array}$ & $\begin{array}{c}\Delta \mathrm{r}_{\mathrm{C}}, \\
\mathrm{m}\end{array}$ & $\begin{array}{c}\text { Mixing } \\
\text { Intensity }^{\mathrm{a}}(\varepsilon), \\
\mathrm{W} / \mathrm{kg}\end{array}$ \\
\hline 2 & 3600 & 0.0017 & 73 \\
\hline 4 & 3600 & 0.0048 & 112 \\
\hline 25 & 1800 & 0.023 & 431 \\
\hline $\begin{array}{c}\text { 4 (test unit with } \\
\text { acrylic housing) }\end{array}$ & $\begin{array}{c}\text { Variable (see } \\
\text { text) }\end{array}$ & 0.0111 & $\begin{array}{c}\text { Variable (see } \\
\text { text) }\end{array}$ \\
\hline
\end{tabular}

a) $\mu=0.0015 \mathrm{~Pa} \bullet \mathrm{s}, \rho=1107 \mathrm{~kg} / \mathrm{m}^{3}$ (average value)

In order to simulate the three rotors using the 4-cm acrylic test unit, the speed of the rotor was varied to obtain the same intensity as the simulated rotor. Hence, three sets of tests were performed at $435 \mathrm{~W} / \mathrm{kg}$ (referred to as "high" mixing intensity), $114 \mathrm{~W} / \mathrm{kg}$ (referred to as "medium" mixing intensity), and $27 \mathrm{~W} / \mathrm{kg}$ (referred to as "low" mixing intensity), corresponding to the 25-, 4-, and 2-cm contactors, respectively. The high, medium, and low intensities were achieved in the 4-cm contactor at rotor speeds of 4830, 3000, and $1800 \mathrm{rpm}$, respectively.

A schematic of the test setup is shown in Fig. 3. Aqueous and organic liquids were introduced to the contactor at an O/A ratio similar to that in the plant - that is, O/A of 0.3 in the extraction section tests and 5 in the strip section tests. A four-component feed [ $2 \underline{\mathrm{M} \mathrm{NaOH}}, 2 \underline{\mathrm{M}}$ $\left.\mathrm{NaNO}_{3}, 0.5 \underline{\mathrm{M} \mathrm{NaNO}} 2,0.3 \underline{\mathrm{M}} \mathrm{Al}\left(\mathrm{NO}_{3}\right)_{3}\right]$ was used to simulate the aqueous raffinate at a flow rate

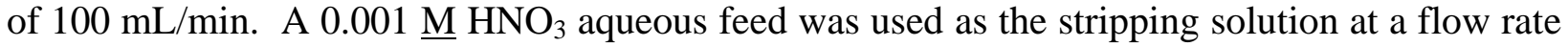
of $6 \mathrm{~mL} / \mathrm{min}$. The CSSX solvent, provided by ORNL, was used as the organic phase in both extraction and strip section tests at a flow rate of $30 \mathrm{~mL} / \mathrm{min}$. 


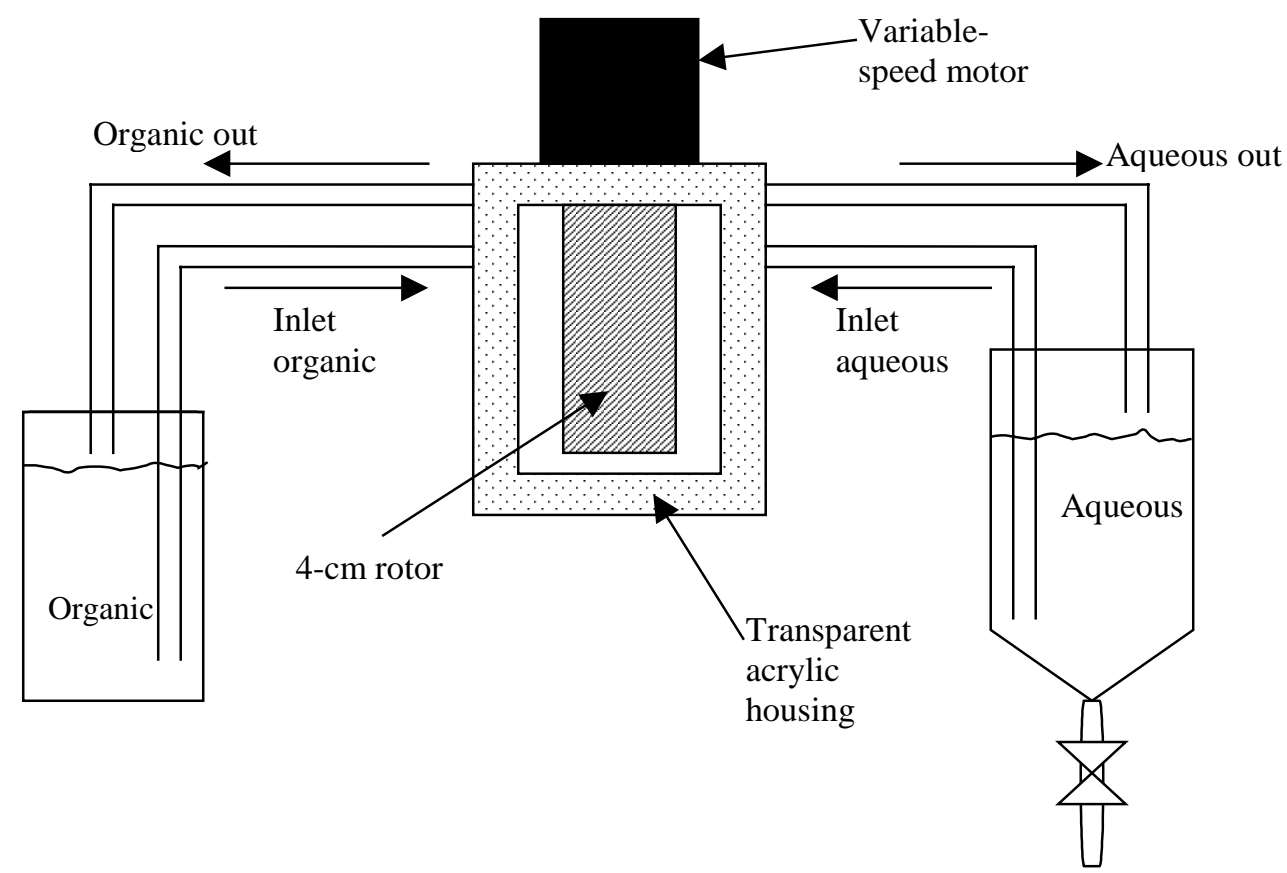

Fig. 3. Schematic of the Experimental Setup for the Decanter Tests

The aqueous phase was placed in a 2000-mL separatory funnel. The funnel was filled with $1800 \mathrm{~mL}$ of simulant in the extraction-section test and $500 \mathrm{~mL}$ of the nitric-acid solution in the strip-section tests. The tip of the aqueous-phase inlet tube was placed near the bottom of the funnel to avoid picking up large droplets of organic phase that would escape to the surface of the separatory funnel. The CSSX solvent was pumped from a $600-\mathrm{mL}$ beaker containing $400 \mathrm{~mL}$ of solvent. The test was started by setting the rotor at the desired speed to provide a low, medium, or high mixing intensity. Then the aqueous flow was started, followed by the organic phase. After running for 2-1/2 hours to allow for steady state to be achieved, a sample was taken from near the bottom of the separatory funnel and analyzed immediately for droplet size distribution of the dispersed organic in the aqueous phase. A light-scattering particle size analyzer, a Beckman-Coulter counter (Model LS100Q, Fullerton, CA), was used for the size distribution measurements. Its effective measuring range is from 1 to $1000 \mu \mathrm{m}$. With the test still running, a second 50-mL sample was taken from the separatory funnel. Five milliliters of diluent (Isopar ${ }^{\circledR} \mathrm{L}$ ) were added to the sample and the two phases were shaken vigorously for a few minutes. They were then allowed to settle overnight to achieve full phase separation. A sample was taken from the organic layer and sent to ORNL for extractant and modifier concentration measurements. Analytical techniques used by ORNL for these analyses were reversed-phase HPLC and high performance gel permeation chromatography (GPC) [MASKARINEC-2001 (b)]. These concentrations were used to calculate the amount of entrained solvent in the $50-\mathrm{mL}$ sample. Although it would have been beneficial, from a statistical standpoint, to collect more than one sample for the entrainment measurements, only one sample was collected for two reasons. First, to collect a representative sample for entrainment measurement, the sample had to be taken from the bottom of the separatory funnel and as far as possible from the surface where the decanted organic phase has accumulated during the test. Since the sample volume $(50 \mathrm{~mL})$ is significant compared with the volume in the funnel, taking additional samples could cause error in the entrainment measurement. Second, only a limited number of samples could be analyzed 
within the budget allocated for ORNL to perform the analyses.

\section{RESULTS AND DISCUSSION}

\section{Entrainment Measurements}

Since the entrained solvent cannot be measured directly, the solvent entrainment in the aqueous effluent was calculated based on the concentration of the extractant and modifier found when $5 \mathrm{~mL}$ of Isopar ${ }^{\circledR} \mathrm{L}$ was used to extract the entrained solvent components from a $50-\mathrm{mL}$ sample of the aqueous effluent. Partitioning limits were subtracted from the measured concentrations to obtain the entrained amounts, as summarized in Appendix A. Entrainment test results are summarized in Table 2, along with the type of aqueous sample (i.e., raffinate or strip) and the mixing intensity. Numbers are reported, as calculated from the experimental concentration measurements, in three significant digits, although this does not necessarily reflect the accuracy of the analytical techniques used. Using six control samples (i.e., samples with known BoBCalixC6 and CS-7SB concentrations), it was determined that the analytical techniques used by ORNL for measuring the concentrations of extractant and modifier were more accurate in the modifier concentration measurement (see Appendix A). This was particularly true at lower concentrations. Therefore, we used the modifier concentration rather than the extractant to calculate the amount of entrainment.

Table 2. Summary of Entrainment Measurement Tests

\begin{tabular}{|c|c|c|c|}
\hline $\begin{array}{c}\text { Aqueous } \\
\text { Effluent }\end{array}$ & $\begin{array}{c}\text { Mixing } \\
\text { Intensity }\end{array}$ & $\begin{array}{c}\text { Appearance of the } \\
\text { Aqueous Effluent }\end{array}$ & $\begin{array}{c}\text { Solvent Entrainment in the } \\
\text { Aqueous Effluent, ppm }\end{array}$ \\
\hline Strip & Low & Clear & 125 \\
\hline Strip & Medium & Hazy & 106 \\
\hline Strip & High & Cloudy & 120 \\
\hline Raffinate & Low & Very cloudy & 241 \\
\hline Raffinate & Medium & Very cloudy & 129 \\
\hline Raffinate & High & Very cloudy & 4 \\
\hline
\end{tabular}

By inspection of Table 2, it can be seen that no clear relationship exists between the mixing intensity and solvent entrainment. As an average, the amount of entrainment in the raffinate solution is $163 \mathrm{ppm}$, while that in the strip solution is $78 \mathrm{ppm}$. Statistical analysis shows that the entrainment values for the strip and raffinate solutions belong to the same "population." Thus, the average entrainment is $121 \mathrm{ppm}$ regardless of the mixing intensity or the type of solution (strip or raffinate). Based on this average entrainment amount and assuming a 240 day/yr operation, the solvent loss, via entrainment, in the pilot plant flowsheet (Fig. 1.) is estimated as follows:

Loss $=(0.2142+0.0133)(\mathrm{gal} / \mathrm{min}) \times 121 \mathrm{E}-6($ gal solvent/gal aqueous $) \times 3.79(\mathrm{~L} / \mathrm{gal}) \times 1900(\$ / \mathrm{L}$ solvent $)$ x $1440(\mathrm{~min} /$ day $) \times 240($ day/yr $)=\$ 68,500 /$ year

For the plant (which has 100 times the capacity of the pilot plant), the solvent loss, via 
entrainment, would be about $\$ 7 \mathrm{M} / \mathrm{yr}$ if no solvent recovery action was taken. This indicates that, particularly for the plant operation, there could be large cost benefit if most of the entrained solvent is recovered and recycled. Note that the annual cost of solvent lost via entrainment is about 11 times the cost of solvent lost via partitioning $(\$ 0.6 \mathrm{M} / \mathrm{yr})$, as calculated earlier.

Also noted in Table 2 is the appearance of the aqueous phase in the separatory funnel at the time when the sample was taken. These observations show no clear relationship between the level of cloudiness of the aqueous phase and the amount of solvent entrained in it. However, it was noticed that solution cloudiness increased with mixing intensity and was always higher for the simulant than for the strip solution. There are two possible explanations for this observation. First, submicron size droplets that cannot be effectively accounted for using the Coulter counter (detection limit about $1 \mu \mathrm{m}$ ) might contribute significantly to the level of cloudiness observed in the aqueous phase. Second, entrained air bubbles, caused by the high mixing intensity, might be responsible for the cloudy appearance of the solution. Both reasons would explain the increase in cloudiness with mixing intensity (Table 2). In any case, cloudiness should not be used to estimate the level of solvent entrainment.

\section{Droplet Size Distribution of Entrained Solvent}

Size distributions of entrained solvent droplets in the raffinate simulant and strip solutions are shown in Fig. 4. For each solution, the distribution is shown for three mixing intensities. The size distributions are also tabulated in Appendix B in a cumulative-volume format. The volume average droplet size for both solutions at the three mixing intensities is given in Table 3. It is observed that, while the size distribution in the strip solution is monomodal with average size at about $130 \mu \mathrm{m}$, the size distribution in the extraction solution is bimodal. Fig. 4(a) shows that the size distributions in the extraction solution have two peaks: the first at a droplet size of about $10 \mu \mathrm{m}$ and the second at a droplet size of $130 \mu \mathrm{m}$. The amount of smaller-size droplets is largest at the high mixing intensity, as shown in Fig. 4(a). This is attributed to the high shear forces at the high mixing intensity, which creates the smaller droplets. The presence of the large-size droplets $(>130 \mu \mathrm{m})$ is attributed to the coalescence of the finer droplets. It is possible, therefore, that the difference in size distributions between the extraction and strip solutions is due to the physical properties of the solutions (density, viscosity, surface tension, etc.). It is also possible that, at the high $\mathrm{pH}$ of the raffinate solution, the smaller droplets do not coalesce as easily to form larger droplets. A third possibility is that, since the residence time of the aqueous phase in the strip stage is 15 times that in the extraction stage, the fine droplets have more time to coalesce. 


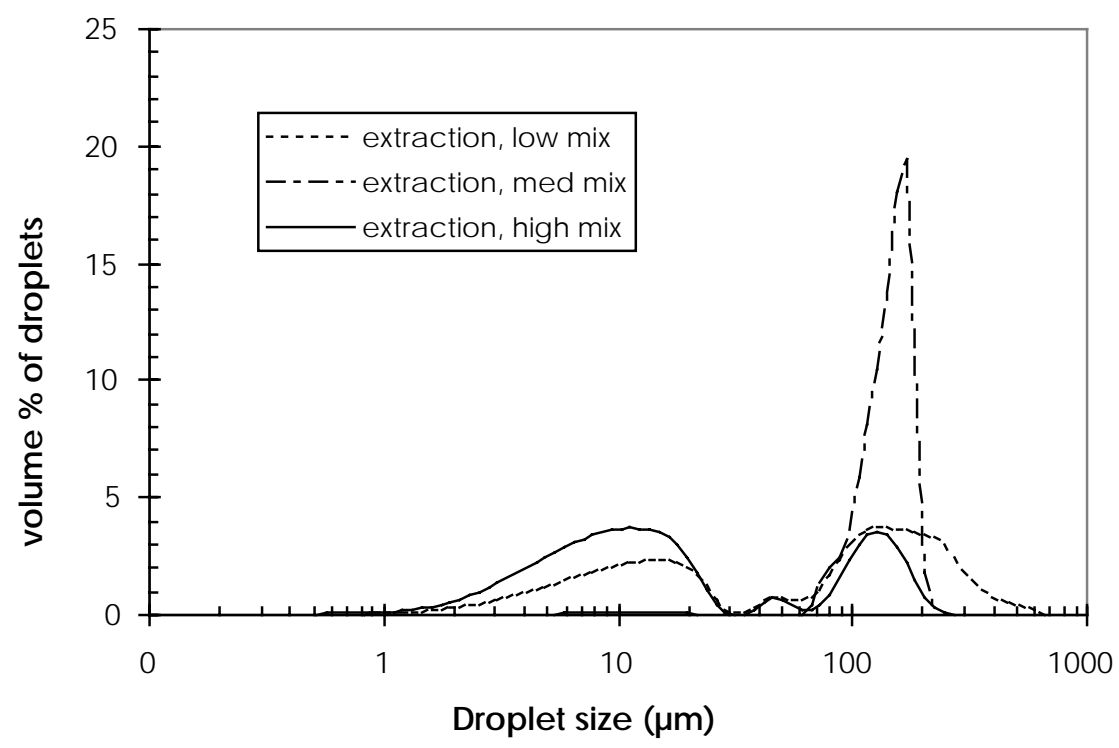

(a) Extraction

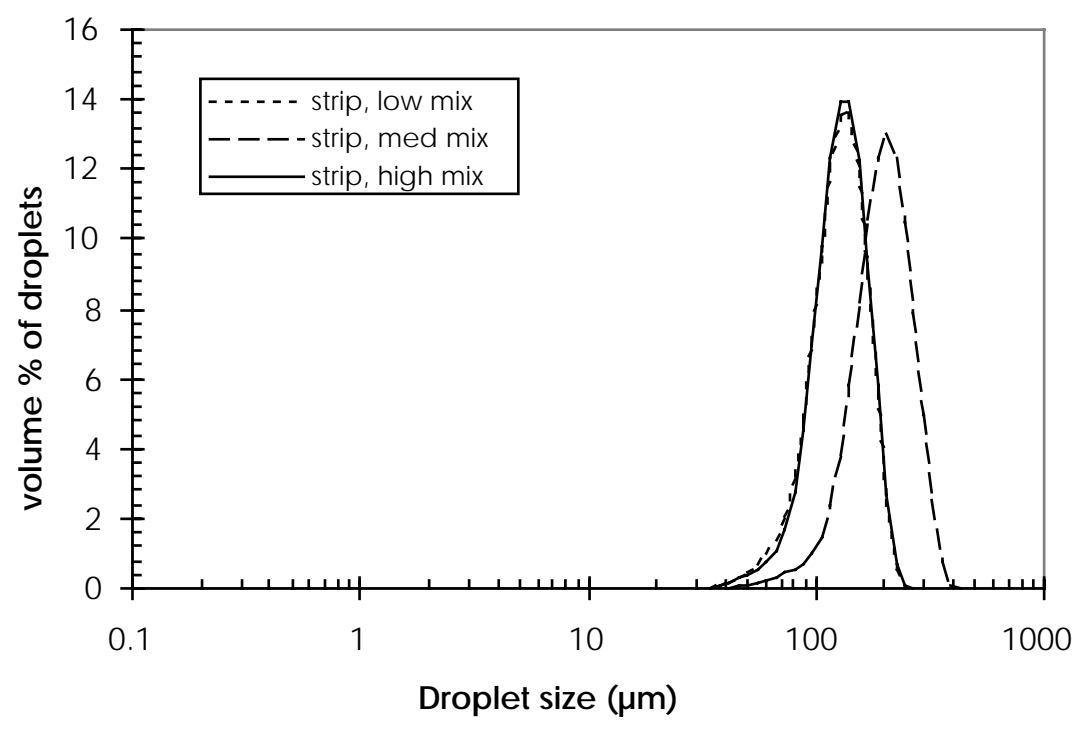

(b) Strip

Fig. 4. Size Distribution of Organic Droplets Entrained in Aqueous Effluents 
Table 3. Average Droplet Size in Raffinate and Strip Effluents

\begin{tabular}{|c|c|c|}
\hline Aqueous Effluent & Mixing Intensity & $\begin{array}{c}\text { Volume-Average Droplet Size, } \\
\mu \mathrm{m}\end{array}$ \\
\hline Strip & Low & 129 \\
\hline Strip & Medium & 200 \\
\hline Strip & High & 130 \\
\hline Extraction & Low & 106 \\
\hline Extraction & Medium & 142 \\
\hline Extraction & High & 43 \\
\hline
\end{tabular}

\section{Decanter Tank Sizing}

Droplet size distributions of the solvent entrained in the raffinate and strip solutions, summarized in Section 2 and tabulated in Appendix B, were used in the calculations of solvent recovery in the fully stilled decanter tank [PERRY-1984], not the simple decanter tank shown in Fig. 3. SRS has not yet finalized a decision on whether decanters will be used in the full-scale plant or if so, the size of the decanters. Hence, in this section we are presenting a sample calculation for the pilot-plant decanter. In the future, as the plant flowsheet becomes finalized, the calculations presented in this section can be modified to include the appropriate size distribution and entrainment values for the high mixing intensity of the plant-scale contactors as well as the plant decanter tank size and geometry. Also, if SRS chooses to use another method for solvent recovery, such as a centrifuge or a coalescer, similar calculations can be performed using the size distribution given in Appendix B. It is also important to note that these calculations reflect only the recovery of entrained solvent (i.e., as a dispersed phase within the aqueous solutions). Gross amounts of solvent in an aqueous effluent due, for example, to hydraulic problems in the contactor, will be captured by any decanter tank, even a simple decanter as shown in Fig. 3. That is because these large solvent volumes will immediately float to the top of the tank liquid. Solvent component partitioned into the aqueous phase, on the other hand, will not be recovered using these techniques. The only method to recover partitioned (i.e., dissolved) solvent components is by contacting the aqueous phase with the organic diluent.

The decanter performance for solvent recovery can be assessed in one of two ways. In the first way, a specific tank volume and geometry is predetermined, for example, based on plant space restrictions. Then, based on droplet size distribution and the amount of entrainment (see Section III.2), the amount of solvent that will be recovered in a fully stilled decanter tank is calculated. The nonrecovered amount can then be compared with the acceptable operation envelope, and the tank size and/or geometry can be revised if the recovery is judged insufficient. In the second way, the amount of solvent recovery needed is predetermined. Then the decanter tank volume is calculated using the droplet size distribution in this document. Since SRS had determined that two 5-gallon decanter tanks would be used in its proposed pilot-plant facility (one for raffinate and the other for aqueous strip effluent), the first method was used to calculate the amount of solvent recovery. Detailed calculations are given in Appendix C. A summary of the results is given here. 
Calculations in Appendix $\mathrm{C}$ show that, by using two standing cylindrical 5-gal decanter tanks (80\% full with liquid height equal to tank diameter) for the two aqueous effluents in a CSSX plant, recovery of the entrained solvent will be $98 \%$ in the raffinate solution and nearly $100 \%$ in the strip solution. Although this is a very good recovery rate for the pilot plant, using decanter tanks might not be a suitable recovery option for the final treatment plant for the following reasons:

- In the treatment plant, a very large decanter tank will be needed to achieve an acceptable rate of solvent recovery from the raffinate. For example, at a feed flow rate of $20.1 \mathrm{gal} / \mathrm{min}$ and assuming a cylindrical tank with a geometry similar to that of the pilot plant, a 3125 -gallon tank (diameter $=2.3 \mathrm{~m}$, height $=2.9 \mathrm{~m}$ ) can achieve only $29 \%$ solvent recovery. To achieve higher recovery values, a much larger tank will be needed.

- In decanter tanks, a proper tank operation requires feeding the liquid to the tank at the interphase zone [PERRY-1984] to ensure minimum liquid disturbances. At an average of 121 ppm organic-in-aqueous carryover, the organic phase will be minimal compared with the aqueous phase, which makes feeding at the interphase zone hard to achieve. For the same reason, continuous removal of recovered solvent from the tank might be impractical.

To overcome these obstacles facing the use of decanter tanks in the plant facility, we recommend evaluating one of the following two alternatives:

- Coalescers: In a coalescer, small drops of a fine dispersion are caused to coalesce and thus become large and more readily separable from the bulk liquid. Coalescers contain mats, beds, or layers of porous or fibrous solids whose properties are especially designed to attract the fine organic droplets, which then collide on these surfaces and form larger droplets. Coalescers are particularly suitable for solvent recovery from the raffinate since (1) the amount of solvent entrained is minimal with respect to the aqueous volume, and (2) a significant portion of the droplets entrained in the raffinate are between 1 and $50 \mu \mathrm{m}$. Using a coalescer will increase the percentage of the larger droplets, facilitating their separation.

- Centrifuge: By utilizing the high g-force of the centrifuge, enhanced phase separation can be achieved and most of the smaller-sized droplets, which are not recovered in a gravity-settling decanter, can be recovered. Commercial centrifuges are available in compact sizes that can process the aqueous effluents in the plant in a continuous fashion.

Although further testing is needed to verify the efficiency of these two alternatives, we believe that using either one of them will provide significant enhancement over the decanter tank, especially for solvent recovery from the aqueous raffinate solution since its flow rate is 16 times that of the aqueous strip effluent. 


\section{SUMMARY AND CONCLUSIONS}

Two sets of tests were performed to simulate the performance of the extraction and strip sections of the contactors in the CSSX process. Each set included tests at low, medium, and high mixing intensity in a single-stage, 4-cm centrifugal contactor. The low-intensity tests simulate the performance of 2-cm (lab-scale) contactors, the medium-intensity tests simulate 4-cm (pilotscale) contactor, and the high-intensity tests simulate $25-\mathrm{cm}$ (full-scale) contactors. During each test, the volume of solvent entrained in the aqueous effluent and the size distribution of the entrained solvent droplets were measured. The average droplet size for the extraction section was $163 \mathrm{ppm}$, while that for the strip section was $78 \mathrm{ppm}$. However, these differences are not statistically significant and an average volume of entrained solvent of $121 \mathrm{ppm}$ was used for all cases. The size distributions for the entrained solvent were also measured. We found more small droplets in the aqueous raffinate from the extraction section than in the aqueous strip effluent.

The droplet size distributions obtained here were used to estimate the amount of solvent recovery achievable in the planned 5-gallon pilot-plant decanter tanks if they are totally stilled. Assuming a cylindrical tank with liquid height equal to tank diameter, the calculations showed that high solvent recovery $(>98 \%)$ is achievable. However, calculations showed that for the final treatment plant, a 3100-gallon decanter tank will be needed to achieve a moderate $30 \%$ solvent recovery from the raffinate effluent. To improve the recovery rate in the plant facility and to overcome other technical difficulties associated with decanter tanks, further testing is needed other means of solvent recovery such as coalescers or centrifuges.

\section{ACKNOWLEDGMENTS}

The authors are grateful for helpful discussions with Mike Maskarinec, Latitia Delmau, and Bruce Moyer from Oak Ridge National Laboratory. This work was supported by the U.S. Department of Energy, Office of Environmental Management, through (1) the Office of Project

Completion and (2) the Tank Focus Area of the Office of Science and Technology under Contract W-31-109-Eng-38. 


\section{REFERENCES}

BONNESEN-2001

P. V. Bonnesen, Oak Ridge National Laboratory, private communication (2001).

\section{CAMPBELL-2001}

S. G. Campbell, M. W. Geeting, C. W. Kennell, J. D. Law, R. A. Leonard, M. A. Norato, R. A. Pierce, T. A. Todd, D. D. Walker, and W. R. Wilmarth, "Demonstration of Caustic-Side Solvent Extraction with Savannah River Site High Level Waste," Westinghouse Savannah River Company Report WSRC-TR-2001-00223 (2001).

\section{HODGES-2000}

M. E. Hodges, "Design Input - Caustic Side Solvent Extraction Flowsheet - Proof of Concept

Testing,” Westinghouse Savannah River Company Report HLW-SDT-2000-000356 (2000).

\section{KNUDSEN-1958}

J. G. Knudsen and D. L. Katz, Fluid Dynamics and Heat Transfer, McGraw-Hill, New York (1958).

\section{LEVENSON-2000}

M. Levenson et al., "Alternatives for High-Level Waste Salt Processing at the Savannah River Site," National Research Council, National Academy Press, Washington, D.C. (2000).

\section{LEONARD-2000}

R. A. Leonard, S. B. Aase, H. A. Arafat, C. Conner, J. R. Falkenberg, and G. F. Vandegrift, "Proof-of-Concept Flowsheet Tests for Caustic-Side Solvent Extraction of Cesium from Tank Waste," Argonne National Laboratory Report ANL-00/30 (2000).

MASKARINEC-2001 (a)

M. P. Maskarinec, Oak Ridge National Laboratory, unpublished data.

MASKARINEC-2001 (b)

M. P. Maskarinec, J. E. Caton, and T. L. White, "Analytical Methods Development in Support of the Caustic Side Solvent Extraction System," Oak Ridge National Laboratory Report CERS/SR/SX/022 (2001).

\section{MOYER-2001}

B. A. Moyer, P. V. Bonnesen, J. E. Caton, C. R. Duchemin, T. G. Levitskaia, F. V. Sloop, S. D. Alexandratos, G. M. Brown, L. H. Delmau, T. J. Haverlock, M. P. Maskarinec, and C. L. Stine, "Caustic-Side Solvent Extraction Chemical and Physical Properties: Progress in FY2000 and FY2001," Oak Ridge National Laboratory Report CERS/SR/SX/019, Rev. 0 (2001).

\section{PERRY-1984}

R. H. Perry and D. Green, Perry's Chemical Engineers' Handbook, $6^{\text {th }}$ edition, McGraw Hill, New York (1984). 


\section{Appendix A}

\section{Entrainment Calculation Data}

In this appendix, the concentration data obtained from ORNL for the entrainment samples are presented (see Section III.1). The data are for two types of samples -- control samples and entrainment samples. Control samples are samples that we prepared at ANL in which the concentrations of the solvent components were known. These control samples were sent, along with the entrainment samples, to ORNL without being identified as control samples. The concentration measurements sent back from ORNL for these samples were compared with the actual concentrations to obtain an insight on the accuracy of measurement techniques. Based on the initial control sample measurements, shown in Table A-1 below, the analytical technique was revised to improve the measurement for the BoBCalixC6. A new reverse-phase HPLC technique was adopted. When the measurements were repeated using the revised technique, a significant improvement was reported in the concentration data for the control samples, as shown in Table A-2. Table A-3 shows the concentration measurements for the entrainment samples, which were obtained using the modified ORNL method. Note that the second and sixth BoBCalixC6 data points seem to be outliers and, therefore, were excluded from calculations of the average entrainment amount using the BoBCalixC6 concentration. The two averages for solvent entrainment, obtained using BoBCalixC6 and modifier concentrations, were reasonably close and well within the standard deviation limit of each other. Because the modifier analyses appeared to be more consistent, the concentration of modifier, rather than the extractant, was used to calculate the entrainment amounts reported in Section III of this report.

\section{Control Samples}

Table A-1. Measurements of Control Samples by ORNL Using the Non-Modified Technique

\begin{tabular}{|c|c|c|c|c|c|c|c|c|}
\hline \multirow{2}{*}{$\begin{array}{l}\text { Sample ID } \\
\text { as Sent to } \\
\text { ORNL }\end{array}$} & \multirow{2}{*}{ Sample Details } & \multicolumn{2}{|c|}{$\begin{array}{l}\text { Results from ORNL } \\
\text { (measured } \\
\text { concentrations) }\end{array}$} & \multicolumn{2}{|c|}{$\begin{array}{l}\text { Expected Concentrations } \\
\text { for Control Samples }\end{array}$} & \multicolumn{2}{|c|}{$\begin{array}{c}\text { Measured Value/Expected } \\
\text { Value }\end{array}$} & \multirow{2}{*}{$\begin{array}{c}\text { Modifier/BoBCalix } \\
\text { Ratio } \\
\text { (expected }=50 \text { ) }\end{array}$} \\
\hline & & $\begin{array}{c}\begin{array}{c}\text { BOBCalixC6 } \\
(\mathrm{M})\end{array} \\
\end{array}$ & $\begin{array}{c}\text { Modifier } \\
(\mathrm{M})\end{array}$ & $\begin{array}{c}\text { BOBCalixC6 } \\
(\mathrm{M})\end{array}$ & $\begin{array}{c}\text { Modifier } \\
(\mathrm{M})\end{array}$ & BOBCalixC6 & Modifier & \\
\hline DSD-1 & Fresh solvent from bottle 4 & $3.73 \mathrm{E}-03$ & $4.48 \mathrm{E}-01$ & $1.00 \mathrm{E}-02$ & $5.00 \mathrm{E}-01$ & 0.373 & 0.895 & 120 \\
\hline DSD-2 & $\begin{array}{l}\text { Solvent after being used } \\
\text { on the first day of testing }\end{array}$ & $4.29 \mathrm{E}-03$ & $5.40 \mathrm{E}-01$ & $1.00 \mathrm{E}-02$ & $5.00 \mathrm{E}-01$ & 0.429 & 1.081 & 126 \\
\hline DSD-4 & $\begin{array}{l}\text { Fresh solvent diluted } 11 \\
\text { times }\end{array}$ & $5.57 \mathrm{E}-04$ & $3.21 \mathrm{E}-02$ & $9.09 \mathrm{E}-04$ & $4.55 \mathrm{E}-02$ & 0.613 & 0.706 & 58 \\
\hline DSD-5 & $\begin{array}{l}\text { Fresh solvent diluted } 51 \\
\text { times }\end{array}$ & $1.18 \mathrm{E}-03$ & $6.04 \mathrm{E}-03$ & 1.96E-04 & $9.80 \mathrm{E}-03$ & 6.020 & 0.616 & 5 \\
\hline DSD-8 & $\begin{array}{l}\text { Solvent after being used } \\
\text { for three days in the strip- } \\
\text { section test }\end{array}$ & $3.82 \mathrm{E}-03$ & $5.05 \mathrm{E}-01$ & $1.00 \mathrm{E}-02$ & $5.00 \mathrm{E}-01$ & 0.382 & 1.011 & 132 \\
\hline DSD-12 & $\begin{array}{l}\text { Solvent after being used } \\
\text { for three days in the } \\
\text { extraction-section test }\end{array}$ & $4.28 \mathrm{E}-03$ & $4.89 \mathrm{E}-01$ & $1.00 \mathrm{E}-02$ & $5.00 \mathrm{E}-01$ & 0.428 & 0.978 & 114 \\
\hline
\end{tabular}

\footnotetext{
${ }^{(1)}$ Expected BoBCalix concentration in the recycled solvent samples take solubility into account
} 
Table A-2. Measurements of Control Samples by ORNL Using the Modified Technique

\begin{tabular}{|c|c|c|c|c|c|c|c|c|}
\hline \multirow{2}{*}{$\begin{array}{l}\text { Sample ID } \\
\text { as Sent to } \\
\text { ORNL }\end{array}$} & \multirow[t]{2}{*}{ Sample Details } & \multicolumn{2}{|c|}{$\begin{array}{l}\text { Results from ORNL } \\
\text { (measured } \\
\text { concentrations) }\end{array}$} & \multicolumn{2}{|c|}{$\begin{array}{l}\text { Expected Concentrations } \\
\text { for Control Samples }\end{array}$} & \multicolumn{2}{|c|}{$\begin{array}{l}\text { Measured Value/Expected } \\
\text { Value }\end{array}$} & \multirow{2}{*}{$\begin{array}{c}\text { Modifier/BoBCalix } \\
\text { Ratio } \\
\text { (expected }=50 \text { ) }\end{array}$} \\
\hline & & $\begin{array}{c}\begin{array}{c}\text { BOBCalixC6 } \\
(\mathrm{M})\end{array} \\
\end{array}$ & $\begin{array}{l}\text { Modifier } \\
\text { (M) }\end{array}$ & $\begin{array}{c}\text { BOBCalixC6 } \\
(\mathrm{M})\end{array}$ & $\begin{array}{l}\text { Modifier } \\
(\mathrm{M})\end{array}$ & BOBCalixC6 & Modifier & \\
\hline DSD-1 & Fresh solvent from bottle 4 & $9.46 \mathrm{E}-03$ & 0.447731 & 0.010000 & 0.500000 & 0.946 & 0.895 & 47 \\
\hline DSD-2 & $\begin{array}{l}\text { Solvent after being used } \\
\text { on the first day of testing }\end{array}$ & $9.38 \mathrm{E}-03$ & 0.540449 & 0.009999 & 0.500000 & 0.938 & 1.081 & 58 \\
\hline DSD-4 & $\begin{array}{l}\text { Fresh solvent diluted } 11 \\
\text { times }\end{array}$ & $1.01 \mathrm{E}-03$ & 0.032108 & 0.000909 & 0.045455 & 1.111 & 0.706 & 32 \\
\hline DSD-5 & $\begin{array}{l}\text { Fresh solvent diluted } 51 \\
\text { times }\end{array}$ & $1.87 \mathrm{E}-04$ & 0.006037 & 0.000196 & 0.009804 & 0.954 & 0.616 & 32 \\
\hline DSD-8 & $\begin{array}{l}\text { Solvent after being used } \\
\text { for three days in the strip- } \\
\text { section test }\end{array}$ & $1.00 \mathrm{E}-02$ & 0.505338 & 0.009997 & 0.500000 & 1.000 & 1.011 & 51 \\
\hline DSD-12 & $\begin{array}{l}\text { Solvent after being used } \\
\text { for three days in the } \\
\text { extraction-section test }\end{array}$ & $9.79 \mathrm{E}-03$ & 0.488768 & 0.010000 & 0.500000 & 0.979 & 0.978 & 50 \\
\hline
\end{tabular}

${ }^{(1)}$ Expected BoBCalix concentration in the recycled solvent samples take solubility into account 
16

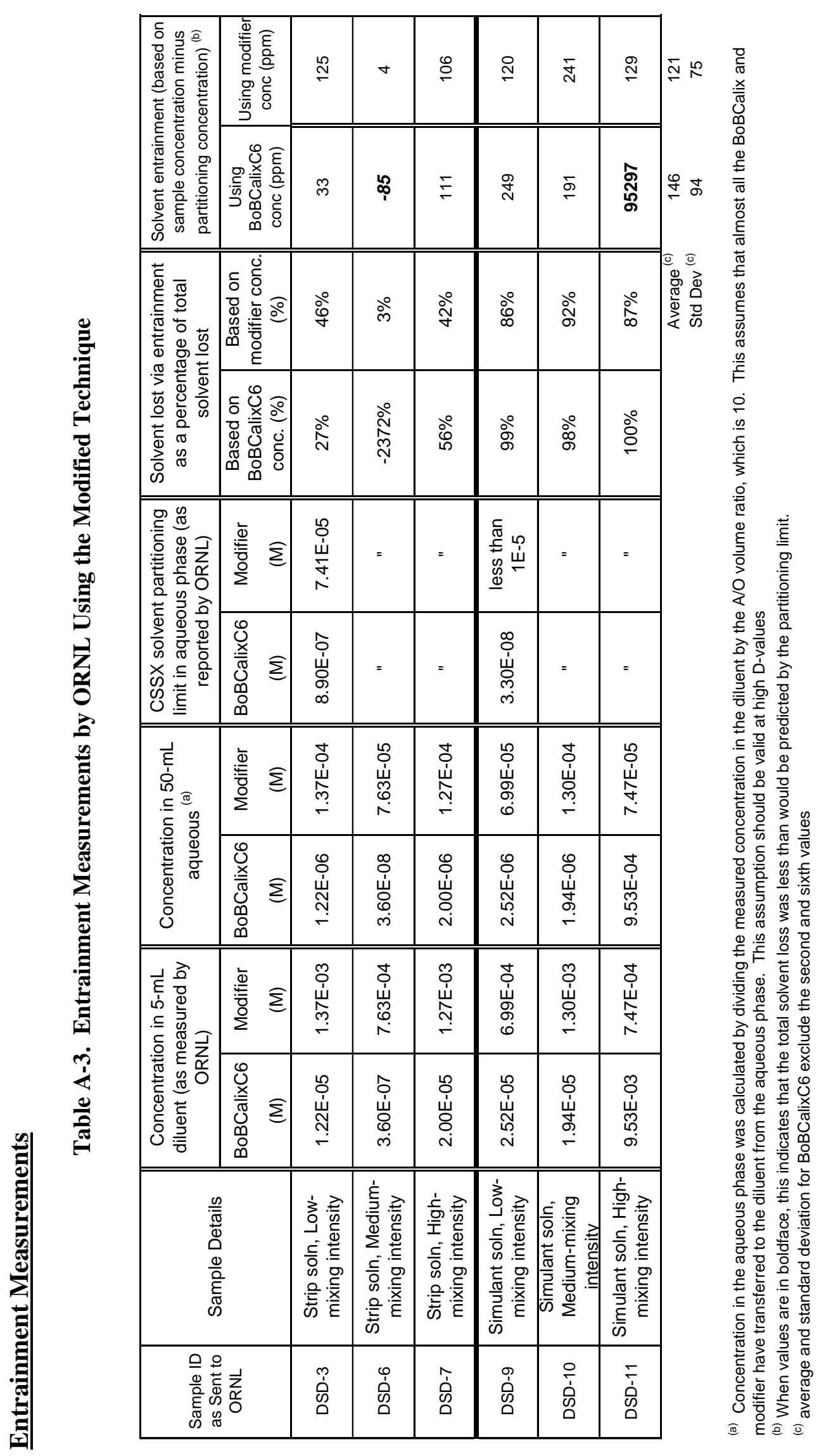




\section{Appendix B}

\section{Cumulative Droplet Size Distribution Data}

Shown below are the cumulative size distributions of entrained organic solvent droplets in the aqueous strip and raffinate solutions. These distribution values were obtained directly from the equipment used to measure the size distribution, which is a light-scattering particle size analyzer, a Beckman-Coulter counter (Model LS100Q, Fullerton CA).

Table B-1. Cumulative Droplet Size Distribution for the Strip Effluent

\begin{tabular}{|c|c|c|c|}
\hline & \multicolumn{3}{|c|}{ Cumulative Volume \% at This Droplet Size } \\
\hline Droplet Size, $\mu \mathrm{m}$ & $\begin{array}{l}\text { Low Mixing } \\
\text { Intensity }\end{array}$ & $\begin{array}{l}\text { Medium Mixing } \\
\text { Intensity }\end{array}$ & High Mixing Intensity \\
\hline 18.0 & 0.0 & 0.0 & 0.0 \\
\hline 19.8 & 0.1 & 0.0 & 0.0 \\
\hline 21.7 & 0.1 & 0.0 & 0.0 \\
\hline 23.8 & 0.1 & 0.0 & 0.0 \\
\hline 26.2 & 0.1 & 0.0 & 0.0 \\
\hline 28.7 & 0.2 & 0.0 & 0.0 \\
\hline 31.5 & 0.2 & 0.0 & 0.0 \\
\hline 34.6 & 0.2 & 0.0 & 0.0 \\
\hline 38.0 & 0.3 & 0.0 & 0.1 \\
\hline 41.7 & 0.5 & 0.1 & 0.3 \\
\hline 45.8 & 0.8 & 0.1 & 0.6 \\
\hline 50.3 & 1.3 & 0.2 & 1.0 \\
\hline 55.2 & 2.0 & 0.3 & 1.5 \\
\hline 60.6 & 3.0 & 0.5 & 2.3 \\
\hline 66.5 & 4.4 & 0.8 & 3.3 \\
\hline 73.0 & 6.5 & 1.2 & 5.0 \\
\hline 80.2 & 9.7 & 1.8 & 7.7 \\
\hline 88.0 & 14.5 & 2.5 & 12.3 \\
\hline 96.6 & 21.5 & 3.5 & 19.2 \\
\hline 106.1 & 31.1 & 4.9 & 29.0 \\
\hline 116.4 & 43.1 & 7.3 & 41.4 \\
\hline 127.8 & 56.7 & 11.1 & 55.3 \\
\hline 140.3 & 70.3 & 16.9 & 69.3 \\
\hline 154.0 & 82.3 & 25.1 & 81.6 \\
\hline 169.0 & 91.3 & 35.6 & 90.8 \\
\hline 185.5 & 96.9 & 48.0 & 96.6 \\
\hline 203.7 & 99.4 & 61.0 & 99.3 \\
\hline 223.7 & 100.0 & 73.3 & 100.0 \\
\hline 245.5 & 100.0 & 83.8 & 100.0 \\
\hline 269.5 & 100.0 & 91.7 & 100.0 \\
\hline 295.9 & 100.0 & 96.7 & 100.0 \\
\hline 324.7 & 100.0 & 99.2 & 100.0 \\
\hline 356.5 & 100.0 & 99.9 & 100.0 \\
\hline 391.4 & 100.0 & 100.0 & 100.0 \\
\hline
\end{tabular}


Table B-2. Cumulative Droplet Size Distribution for the Aqueous Raffinate

\begin{tabular}{|c|c|c|c|}
\hline & \multicolumn{3}{|c|}{ Cumulative Volume \% at This Droplet Size } \\
\hline $\begin{array}{c}\text { Droplet Size, } \\
\mu \mathrm{m}\end{array}$ & $\begin{array}{l}\text { Low Mixing } \\
\text { Intensity }\end{array}$ & $\begin{array}{l}\text { Medium Mixing } \\
\text { Intensity }\end{array}$ & High Mixing Intensity \\
\hline 0.4 & 0.0 & 0.0 & 0.0 \\
\hline 0.5 & 0.1 & 0.0 & 0.1 \\
\hline 0.6 & 0.1 & 0.0 & 0.2 \\
\hline 0.7 & 0.1 & 0.0 & 0.3 \\
\hline 0.8 & 0.2 & 0.0 & 0.5 \\
\hline 0.9 & 0.3 & 0.0 & 0.6 \\
\hline 1.0 & 0.4 & 0.0 & 0.8 \\
\hline 1.1 & 0.5 & 0.0 & 0.9 \\
\hline 1.2 & 0.6 & 0.0 & 1.1 \\
\hline 1.3 & 0.7 & 0.0 & 1.3 \\
\hline 1.5 & 0.9 & 0.0 & 1.6 \\
\hline 1.6 & 1.0 & 0.0 & 2.0 \\
\hline 1.8 & 1.3 & 0.0 & 2.5 \\
\hline 1.9 & 1.5 & 0.1 & 3.0 \\
\hline 2.1 & 1.8 & 0.1 & 3.7 \\
\hline 2.3 & 2.2 & 0.1 & 4.5 \\
\hline 2.5 & 2.7 & 0.1 & 5.5 \\
\hline 2.8 & 3.2 & 0.1 & 6.7 \\
\hline 3.1 & 3.9 & 0.1 & 8.1 \\
\hline 3.4 & 4.6 & 0.2 & 9.6 \\
\hline 3.7 & 5.4 & 0.2 & 11.4 \\
\hline 4.1 & 6.4 & 0.2 & 13.4 \\
\hline 4.4 & 7.5 & 0.2 & 15.6 \\
\hline 4.9 & 8.7 & 0.2 & 18.1 \\
\hline 5.4 & 10.0 & 0.3 & 20.7 \\
\hline 5.9 & 11.4 & 0.4 & 23.6 \\
\hline 6.5 & 13.0 & 0.4 & 26.7 \\
\hline 7.1 & 14.8 & 0.5 & 29.9 \\
\hline 7.8 & 16.6 & 0.6 & 33.3 \\
\hline 8.5 & 18.6 & 0.7 & 36.8 \\
\hline 9.4 & 20.6 & 0.8 & 40.4 \\
\hline 10.3 & 22.8 & 0.9 & 44.1 \\
\hline 11.3 & 25.0 & 1.0 & 47.7 \\
\hline 12.4 & 27.3 & 1.1 & 51.4 \\
\hline 13.6 & 29.6 & 1.2 & 55.0 \\
\hline 15.0 & 31.9 & 1.3 & 58.5 \\
\hline 16.4 & 34.2 & 1.4 & 61.9 \\
\hline 18.0 & 36.4 & 1.5 & 64.9 \\
\hline 19.8 & 38.5 & 1.6 & 67.4 \\
\hline 21.7 & 40.2 & 1.6 & 69.2 \\
\hline 23.8 & 41.5 & 1.6 & 70.2 \\
\hline 26.2 & 42.1 & 1.6 & 70.6 \\
\hline 28.7 & 42.4 & 1.6 & 70.7 \\
\hline 31.5 & 42.5 & 1.6 & 70.7 \\
\hline 34.6 & 42.6 & 1.6 & 70.7 \\
\hline 38.0 & 42.9 & 1.6 & 71.0 \\
\hline
\end{tabular}




\begin{tabular}{|c|c|c|c|}
\hline \multicolumn{4}{|c|}{ Table B-2. (cont.) } \\
\hline & \multicolumn{3}{|c|}{ Cumulative Volume \% at This Droplet Size } \\
\hline Droplet size, $\mu \mathrm{m}$ & $\begin{array}{l}\text { Low Mixing } \\
\text { Intensity }\end{array}$ & $\begin{array}{l}\text { Medium Mixing } \\
\text { Intensity }\end{array}$ & High Mixing Intensity \\
\hline 41.7 & 43.6 & 1.6 & 71.5 \\
\hline 45.8 & 44.3 & 1.6 & 72.2 \\
\hline 50.3 & 45.1 & 1.6 & 72.8 \\
\hline 55.2 & 45.7 & 1.6 & 73.2 \\
\hline 60.6 & 46.4 & 1.6 & 73.5 \\
\hline 66.5 & 47.1 & 2.0 & 73.7 \\
\hline 73.0 & 48.2 & 3.4 & 74.1 \\
\hline 80.2 & 49.9 & 5.5 & 74.9 \\
\hline 88.0 & 52.3 & 7.9 & 76.5 \\
\hline 96.6 & 55.3 & 11.6 & 78.8 \\
\hline 106.1 & 58.7 & 17.4 & 81.8 \\
\hline 116.4 & 62.4 & 25.5 & 85.2 \\
\hline 127.8 & 66.1 & 35.9 & 88.8 \\
\hline 140.3 & 69.8 & 49.7 & 92.1 \\
\hline 154.0 & 73.4 & 67.8 & 95.1 \\
\hline 169.0 & 77.0 & 87.2 & 97.3 \\
\hline 185.5 & 80.6 & 98.2 & 98.8 \\
\hline 203.7 & 84.0 & 100.0 & 99.6 \\
\hline 223.7 & 87.3 & 100.0 & 99.9 \\
\hline 245.5 & 90.2 & 100.0 & 100.0 \\
\hline 269.5 & 92.7 & 100.0 & 100.0 \\
\hline 295.9 & 94.7 & 100.0 & 100.0 \\
\hline 324.7 & 96.1 & 100.0 & 100.0 \\
\hline 356.5 & 97.2 & 100.0 & 100.0 \\
\hline 391.4 & 98.0 & 100.0 & 100.0 \\
\hline 429.7 & 98.6 & 100.0 & 100.0 \\
\hline 471.7 & 99.1 & 100.0 & 100.0 \\
\hline 517.8 & 99.5 & 100.0 & 100.0 \\
\hline 568.4 & 99.8 & 100.0 & 100.0 \\
\hline 624.0 & 99.9 & 100.0 & 100.0 \\
\hline 685.0 & 100.0 & 100.0 & 100.0 \\
\hline
\end{tabular}




\section{Appendix C}

\section{Calculations for Solvent Recovery in a CSSX Pilot-Plant Decanter Tank}

Two decanter tanks will be used in the pilot-plant facility (the first for recovery from the aqueous raffinate and the second for recovery from the aqueous strip solution). The total volume of each decanter is 5 gallons. A cylindrical tank geometry is assumed with liquid height in the tank $(\mathrm{H})$ equal to the tank diameter (D) (see sketch below).

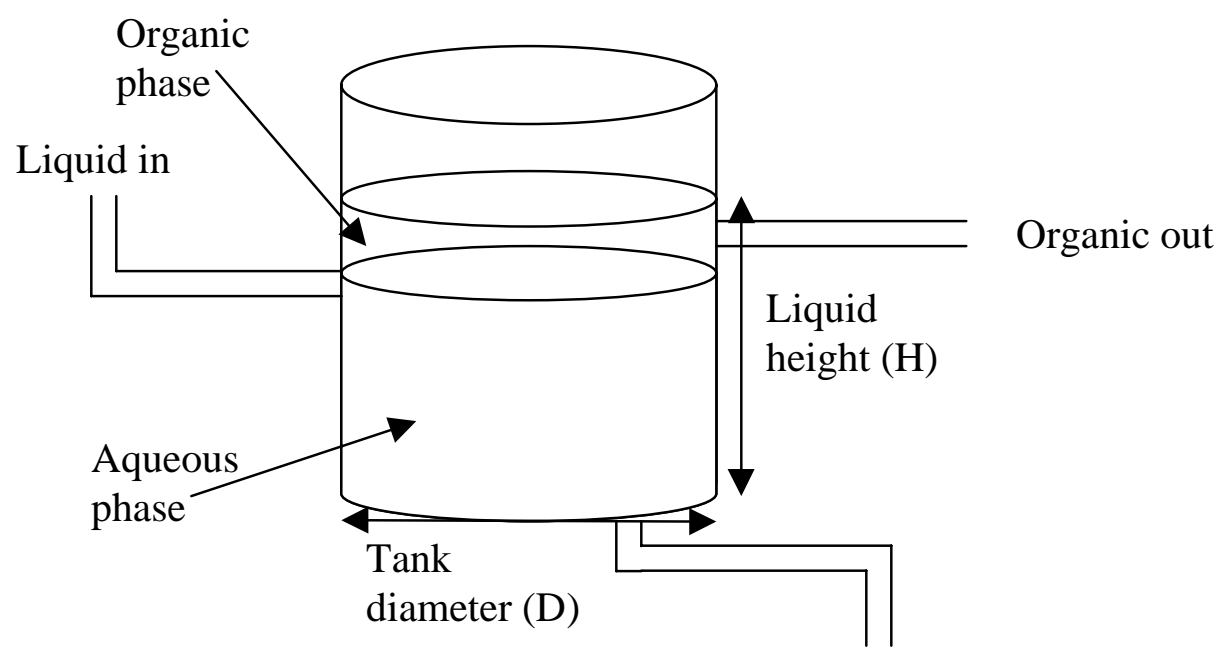

Aqueous out

The decanter tank is assumed to be $80 \%$ full, i.e., liquid volume $=4$ gallon. Therefore,

$$
\text { Liquid volume }(\mathrm{V})=\frac{\pi \mathrm{D}^{2}}{4} H=\frac{\pi \mathrm{D}^{3}}{4}=4 \text { gallon }=0.0151 \mathrm{~m}^{3}
$$

Then, solving for $\mathrm{D}$ gives

$$
\mathrm{D}=\mathrm{H}=0.27 \mathrm{~m}
$$

The superficial velocity $\left(\mathrm{v}_{\mathrm{L}}\right)$ of the liquid moving downward in the tank is

$$
\mathrm{v}_{\mathrm{L}}=\frac{\text { Volumetric aqueous effluent flow rate }}{\text { Tank cross - sectional area }}
$$

For the raffinate tank, the superficial velocity $\left(\mathrm{v}_{\mathrm{L}, \mathrm{r}}\right)$ is 
$\mathrm{v}_{\mathrm{L}, \mathrm{r}}=\frac{1.39 \mathrm{E}-5 \mathrm{~m}^{3} / \mathrm{s}}{5.73 \mathrm{E}-2 \mathrm{~m}^{2}}=2.43 \mathrm{E}-4 \mathrm{~m} / \mathrm{s}$

For the strip solution tank, the superficial velocity $\left(\mathrm{v}_{\mathrm{L}, \mathrm{s}}\right)$ is

$$
\mathrm{V}_{\mathrm{L}, \mathrm{s}}=\frac{9.27 \mathrm{E}-7 \mathrm{~m}^{3} / \mathrm{s}}{5.73 \mathrm{E}-2 \mathrm{~m}^{2}}=1.62 \mathrm{E}-5 \mathrm{~m} / \mathrm{s}
$$

Hence, the minimum upward velocity of a droplet $\left(\mathrm{v}_{\mathrm{d}, \mathrm{r}}\right)$ to be decanted in the raffinate tank is $2.43 \mathrm{E}-4 \mathrm{~m} / \mathrm{s}$, and that of a droplet in the strip solution tank $\left(\mathrm{v}_{\mathrm{d}, \mathrm{s}}\right)$ is $1.62 \mathrm{E}-5 \mathrm{~m} / \mathrm{s}$.

Using Stoke's Law:

$$
\mathrm{v}_{\mathrm{d}}=\frac{9.81\left(\mathrm{~d}^{2}\right)(\Delta \rho)}{18 \mu}
$$

where

$\mathrm{v}_{\mathrm{d}}=$ upward droplet velocity, $\mathrm{m} / \mathrm{s}$

$\mathrm{d}=$ droplet diameter, $\mathrm{m}$

$\bullet \rho=$ difference in density of the two phases (aqueous and organic), $\mathrm{kg} / \mathrm{m}^{3}$, and $\mu=$ viscosity of the continuous phase, $\mathrm{Pa} \bullet \mathrm{s}$

The densities of the raffinate solution, strip solution, and solvent are about 1200, 1000, and 826 $\mathrm{kg} / \mathrm{m}^{3}$, respectively. The viscosity is assumed to be $0.0015 \mathrm{~Pa} \bullet \mathrm{s}$ for both aqueous solutions.

Substituting in Stoke's Law for the aqueous raffinate, the minimum droplet diameter that can escape from the down-flowing aqueous phase $\left(d_{r}\right)$ is $42 \mu \mathrm{m}$. Similarly, for the aqueous strip effluent, the minimum droplet diameter $\left(d_{s}\right)$ is $16 \mu \mathrm{m}$.

Using the cumulative size distribution in Appendix B, the cumulative volume of droplets smaller than $42 \mu \mathrm{m}$ in the raffinate solution, at medium mixing intensity (expected in the pilot plant), is $1.6 \%$. Therefore, $98.4 \%$ of the entrained solvent will be recovered. For the strip solution at medium mixing intensity, $0 \%$ of the droplets are of size $16 \mu \mathrm{m}$ or less. Hence, $100 \%$ of the entrained solvent will be recovered. 
$\underline{\text { Distribution List for ANL-02/08 }}$

Internal (Printed and Electronic Copies):
S. B. Aase
A. V. Guelis
K. L. Nash
H. A. Arafat (5)
M. C. Hash
A. J. Bakel
A. S. Hebden
M. C. Regalbuto (5)
D. B. Chamberlain
J. E. Helt
M. J. Steindler
Y. I. Chang
M. D. Kaminski
G. F. Vandegrift
M. L. Dietz
R. A. Leonard (5)
E. Freiberg
D. Lewis (2)
S. K. Zussman

Internal (Electronic Copy Only):
D. L. Bowers
R. J. Finch
E. C. Gay
C. J. Mertz
J. Sedlet
TIS Files

\section{External (Printed and Electronic Copies):}

Chemical Technology Division Review Committee Members:

H. U. Anderson, University of Missouri-Rolla, Rolla, MO

A. L. Bement, Jr., Purdue University, West Lafayette, IN

C. L. Hussey, University of Mississippi, University, MS

M. V. Koch, University of Washington, Seattle, WA

V. P. Roan, Jr., University of Florida, Gainesville, FL

J. R. Selman, Illinois Institute of Technology, Chicago, IL

J. S. Tulenko, University of Florida, Gainesville, FL

J. F. Birdwell, Oak Ridge National Laboratory, Oak Ridge, TN

P. V. Bonnesen, Oak Ridge National Laboratory, Oak Ridge, TN

S. G. Campbell, Westinghouse Savannah River Company, Aiken, SC

J. T. Carter, Westinghouse Savannah River Company, Aiken, SC

C. Conner, Bolingbrook, IL

L. H. Delmau, Oak Ridge National Laboratory, Oak Ridge, TN

H. D. Harmon, Westinghouse Savannah River Company, Aiken, SC

R. T. Jubin, Oak Ridge National Laboratory, Oak Ridge, TN

J. D. Law, Idaho National Engineering and Environmental Laboratory, Idaho Falls, ID

R. Leugemors, Pacific Northwest National Laboratory, Richland, WA

B. A. Moyer, Oak Ridge National Laboratory, Oak Ridge, TN

M. Norato, Westinghouse Savannah River Company, Aiken, SC

R. A. Pierce, Westinghouse Savannah River Company, Aiken, SC

P. C. Suggs, DOE-SR, Aiken, South Carolina

M. C. Thompson, Westinghouse Savannah River Company, Aiken, SC

T. A. Todd, INEEL, Idaho Falls, ID

D. D. Walker, Westinghouse Savannah River Company, Aiken, SC 


\section{External (Printed Copy Only):}

ANL-E-Library

ANL-W-Library

Tanks Focus Area Technical Team, c/o B. J. Williams, Pacific Northwest National Laboratory, Richland, WA

Tanks Focus Area Field Lead, c/o T. P. Pietrok, Richland Operations Office, Richland, WA Tanks Focus Area Headquarters Program Manager, c/o, K. D. Gerdes, DOE-EM, Germantown, MD

External (Electronic Copy Only):

DOE-OSTI

W. D. Clark, DOE-SR, Aiken, SC

S. M. Dinehart, Los Alamos National Laboratory, Los Alamos, NM

R. E. Edwards, Westinghouse Savannah River Company, Aiken, SC

S. D. Fink, Westinghouse Savannah River Company, Aiken, SC

L. N. Klatt, Oak Ridge National Laboratory, Oak Ridge, TN

D. E. Kurath, Battelle, Pacific Northwest National Laboratory, Richland, WA

K. T. Lang, USDOE, Washington, DC

J. W. McCullough, USDOE, Aiken, SC

C. P. McGinnis, Oak Ridge National Laboratory, Oak Ridge, TN

A. L. Olson, Idaho National Engineering and Environmental Laboratory, Idaho Falls, ID

M. J. Palmer, Los Alamos National Laboratory, Los Alamos, NM

L. M. Papouchado, Westinghouse Savannah River Company, Aiken, SC

R. A. Peterson, Bechtel-Washington Process Technology, Richland, WA

B. M. Rapko, Battelle, Pacific Northwest National Laboratory, Richland, WA

R. D. Rogers, University of Alabama, Tuscaloosa, AL

K. J. Rueter, Bechtel-Washington Process Technology, Richland, WA

P. Rutland, Bechtel-Washington Process Technology, Richland, WA

S. N. Schlahta, Battelle, Pacific Northwest National Laboratory, Richland, WA

J. L. Swanson, Richland, WA

W. L. Tamosaitis, Westinghouse Savannah River Company, Aiken, SC

L. L. Tavlarides, Syracuse University, Syracuse, NY

D. W. Tedder, Georgia Institute of Technology, Atlanta, GA

V. Van Brunt, University of South Carolina, Columbia, SC

J. F. Walker, Oak Ridge National Laboratory, Oak Ridge, TN

J. S. Watson, Oak Ridge National Laboratory, Oak Ridge, TN

R. M. Wham, Oak Ridge National Laboratory, Oak Ridge, TN

W. R. Wilmarth, Westinghouse Savannah River Company, Aiken, SC 
